\title{
Assessment of Heavy Metals Contamination in Drinking Water of Garmian Region, Kurdistan, Iraq
}

\author{
Hayder Mohammed Issa ${ }^{1}$, Azad H. Alshatteri ${ }^{2}$ \\ ${ }^{1}$ College of Human Sciences, University of Garmian, Sulaymaniyah Province 46021, Kurdistan Region, Iraq, ${ }^{2}$ Department \\ of Chemistry, College of Education, University of Garmian, Sulaymaniyah Province 46021, Kurdistan Region, Iraq
}

\section{A B S T R A C T}

Drinking water of safe quality is a critical issue for human survival and health. Water pollution by heavy metals is very crucial because of their toxicity. This study assesses the potential of heavy metal pollution in drinking water in the three districts of Garmian Region, East Iraq. Water samples were investigated for 23 heavy metals and 6 chemical contaminants collected from 16 locations between January 1 and October 31 in 2017 . The analysis was performed using inductively coupled plasma optical emission spectroscopy (ICPOES, Spectro Arcos). High levels of Al, Se, Sr, and Fe have been detected at certain locations in the study area. Statistical analysis techniques of the correlation matrix and cluster hierarchical analysis were conducted. The heavy metals pollution index (HPI), heavy metals evaluation index (HEI), and contamination index $\left(\mathrm{C}_{d}\right)$ were applied. These indices linked with the statistical analysis to interpret relationships among tested parameters in water samples and to investigate pollution sources over the study region. Even with the significant correlations between the $\mathrm{HPI}, \mathrm{C}_{d^{\prime}}$ and $\mathrm{HEl}$, they showed a dissimilar impact of examined heavy metals on the water quality. It was found that concentrations of heavy metals such as $\mathrm{Al}, \mathrm{Fe}$, and Se are in elevation $10.550,0.736$, and $0.044) \mathrm{mg} / \mathrm{l}$, respectively, at certain locations depending on the last update of the WHO guidelines for drinking water. The most reliable pollution evaluation index of HEl for drinking water showed that $44 \%$ of the water samples is critically polluted. Sources of the contamination are most likely coming from natural geological sources. The anthropogenic impact was only noticed at several sites in the study area.

Index Terms: Drinking Water, Environmental Risk Assessment, Garmian Region, Heavy Metals, Multivariate Statistical Analysis

\section{INTRODUCTION}

Drinking water pollution is becoming an increasing problem in the entire world for its severity and toxic effects on human health. The continuous development of significant changes

\begin{tabular}{|l|l|}
\hline \multicolumn{2}{|c|}{ Access this article online } \\
\hline Dol: 10.21928/uhdjst.v2n2y2018.pp40-53 & $\begin{array}{l}\text { E-ISSN: 2521-4217 } \\
\text { P-ISSN: 2521-4209 }\end{array}$ \\
\hline $\begin{array}{l}\text { Copyright } @ 2018 \text { Issa, et al. This is an open access article distributed } \\
\text { under the Creative Commons Attribution Non-Commercial No } \\
\text { Derivatives License 4.0 (CC BY-NC-ND 4.0) }\end{array}$ \\
\hline
\end{tabular}

such as population growth, industrialization, expanding urbanization, and diminishing water resources made the issue much worst [1]. Awareness of the quality of drinking water is expanding steadily in many countries in the world [2]. Heavy metals play a reasoned approach to the classifying of drinking water quality due to their toxicity and poisonousness even at low quantities [3]. Heavy metals are the most damaging and dangerous contaminants in water due to non-biodegradable nature and their accumulation in a biological system [4]. Drinking water may contain essential and toxic heavy metals. The essential metals are Co, Cr, Fe, Mn, Mo, Ni, Se, Sn, V, $\mathrm{Cu}$, and $\mathrm{Zn}$, these metals are critical for sustain biological life, but still, their accumulation in the body may cause dangerous

\footnotetext{
Corresponding author's e-mail: Hayder Mohammed Issa, University of Garmian, Sulaymaniyah Province 46021, Iraq. Phone: +9647708617536. E-mail: hayder.mohammed@garmian.edu.krd
} 
effects [5]. The toxic and non-essential heavy metals such as contamination index $\left(\mathrm{C}_{\mathrm{d}}\right), \mathrm{Pb}, \mathrm{Al}, \mathrm{As}, \mathrm{Ba}, \mathrm{Hg}, \mathrm{Be}$, and Ti are toxic can cause critical or chronic poisoning [6], [7]. For the past years, various works have been performed to identify heavy metals pollution in drinking water [8]-[11]. Any reliable assessment for water quality needs to take into account more chemical parameters such as $\mathrm{Ca}, \mathrm{Na}, \mathrm{Mg}, \mathrm{PO} 4, \mathrm{NO} 3, \mathrm{SO} 4$, and total hardness. To obtain a total view on drinking water quality condition, as the chemical parameters in drinking water may cause important environmental and sanitary consequences [12]. Assessment of drinking water quality requires to recognize regional geogenic and anthropogenic characteristics for an area to be studied. Naturally, heavy metals reach water resources by leaching from contacting the soil and underlying rocks. Heavy metals may come from anthropogenic activities such as agricultural run-off, effluents discharged from cities, industrial plants, and mining sites of heavy metals [13]-[15].

Evaluating heavy metals traces in drinking water have been performed by generating pollution indices. These indices refer to the overall water quality in terms of heavy metals contamination. Many indices are used for the purpose concerned, such as heavy metals pollution index (HPI), heavy metals evaluation index (HEI), and the degree of $C_{d}[16]$ [18]. $C_{d}$ is distinguished by the fact that it implicates heavy metals and other coexisting contaminants in water quality evaluation [19].

Many parts of Iraq, including the Garmian Region, are suffering from the low quality and pollution of their drinking water sources [20]-[22]. As a result, several attempts to have been made to define the potential risk of drinking water quality in the area concerned [23]. However, up until now, no extensive analysis has been performed to identify heavy metals levels in drinking water at Garmian Region.

The current study tests the heavy metal concentration levels in drinking water of Garmian Region, East Iraq by establishing a reliable dataset that aids further investigations to develop remediation strategies, to enhance the environment of the region, and to protect people health. This work investigates 23 heavy metals and six chemical parameters in drinking water samples from 16 different locations in Garmian Region. HPI, HEI, $C_{d}$, with statistical analysis approaches of ANOVA, the correlation matrix $(\mathrm{CM})$, and cluster analysis cluster hierarchical analysis (CA) have been carried out to detect the possible pollution sources.

\section{MATERIALS AND METHODS}

\subsection{Study Area}

Garmian Region is located between latitudes ( $34^{\circ} 17^{\prime} 15^{\prime \prime}$ $\left.35^{\circ} 10^{\prime} 35^{\prime \prime}\right)$ North and longitudes ( $\left.44^{\circ} 31^{\prime} 30^{\prime \prime}-45^{\circ} 47^{\prime} 10^{\prime \prime}\right)$ East. (Fig. 1), the study area has a total area of $6716.5 \mathrm{~km}^{2}$ in three districts Kalar, Kifri, and Khanaqin. The region has a population of 300,000 inhabitants, with no major industrial constructions. The physicographic feature of the area is an alluvial plain in the south and west; while the area lies within foothill in the north and east. The major river systems draining the area include Alwand, Diyala-Sirwan, and Awaspi Rivers. A climate of the study area is continental semiarid by potential evaporation [24]. Soil order of the area is mainly aridisols [25]. The land surface is covered by sand, silt, and clay, while periodically several areas are covered by gravel [26]. Many parts of the study area are rich with gypsum minerals [27]. The area is underlain by the outcropping formations of Tertiary (Pliocene), and the Quaternary deposits (Pleistocene-Holocene) consist in the alternation of sandstone, siltstone, and claystone [28].

\subsection{Collection of Water Samples}

Water samples (surface and groundwater) were collected from the study area and sampling locations from 16 locations in Garmian districts between January 1 and October 31 in 2017, three samples were collected from each location. Water sample was collected from selected sites, where including different water systems and an area covered a stretch of about 60-70 km.

In the field a clean pre-washed $(250 \mathrm{ml}$.) polyethylene bucket, which had been connected with a long rope used for

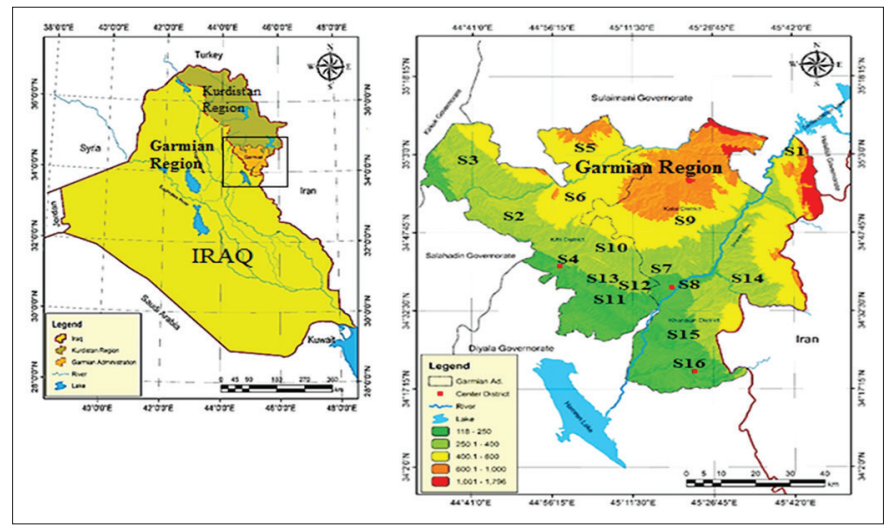

Fig. 1. Map of study area, and locations of water sampling (The first map of Garmian Region Topography is Courtesy of Garmian Region Directorate 2017, the second map of Garmian Region location according to Kurdistan Region, and Iraq was modified by the authors). 
collection of water samples from different sampling sites. The water sample was allowed to pass through the bucket for a while.

Samples were identified in Table I. All samples were acidified with $2 \%$ nitric acid ( $\mathrm{pH}-2)$, and refrigerated and transferred to the instrumental research laboratory to analyze them. All samples were analyzed within 2 days from the time of collection by inductively coupled plasma optical emission spectroscopy (ICPOES) (Spectro across Germany) at University of Garmian. The standard solutions were prepared by serial dilutions of the $1000 \mathrm{mg} / \mathrm{L}$. Distilled deionized water was used for the dilutions and the washing all glassware [4].

\subsection{Heavy Metals Analysis}

Various accurate analytical methods are applied to determine heavy metals concentrations in water samples such as the atomic absorption spectrometry AAS [29], [30], the ICPOES [31]-[33], and the inductively coupled plasma mass spectrometry ICP-MS [34].

All water samples were stored in polyethylene containers and returned to the laboratory under dark conditions within 1-2 h of collection time. The water samples were acidified by adding concentrated nitric acid $\mathrm{HNO}_{3}$ and sored at $25^{\circ} \mathrm{C}$ for trace metal determination purposes.

ICP-OES: Spectro Arcos was used to analyze the 23 heavy metals. The instrument conditions used were: Spray chamber is Scott spray; Nebulizer: Crossflow; RF power/W: 1400; pump speed: $30 \mathrm{RPM}$; Coolant flow (L/min): 14; Auxiliary flow (L/min): 0.9; nebulizer gas flow (L/min): 0.8; Preflush (s): 40; Measure time (s): 28; replicate measurement: 3; argon gas (purity $\geq 99.99$ ); multi-elements stock solutions containing $1000 \mathrm{mg} / \mathrm{L}$ were obtained from Bernd Kraft (Bernd Kraft GmbH, Duisburg, Germany); and standard solutions were diluted by several dilution into $0.1,0.5$, and $2 \mathrm{ppm}$ in $0.5 \%$ nitric acid as diluent [2].

\subsection{Statistical Analysis}

Water pollution indices and statistical approaches were implemented to evaluate the potential sources and levels of heavy metals. Typically, evaluation of water quality by pollution indices depends on a massive dataset collected for various relevant contamination parameters in water samples at different locations. Application of water pollution indices is associated with various statistical analytical techniques to interpret and classify the obtained water quality data sets. However, among the numerous available statistical techniques, the univariate ANOVA, the bivariate correlation coefficient matrix $\mathrm{CM}$, and the multivariate cluster analysis $\mathrm{CA}$ are used for heavy metals impact on water quality [35], [36]. Sometimes, these statistical become helpful as water quality results may require additional explanations to identify source and way of the contamination.

The obtained data sets from water samples were subjected to statistical analysis using Excel 2013 software. Two statistical analysis that performed to deduce the sources of heavy metals were; ANOVA and CM interpretations, and cluster analysis CA. Using ANOVA aids to find out the significance of the variation between sampling locations while a $\mathrm{CM}$ was used to reveal the relationships between the examined heavy metals and chemical contaminants. Cluster analysis was applied in this work to classify water samples according to their spatial

\section{TABLE I: The description of sources of water samples}

\begin{tabular}{|c|c|c|c|c|}
\hline Sampling Symbol & Samples & Location & Site coordinate & Source \\
\hline S1 & Mineral water & Bani-khailan, Kalar district & $35.07,45.67$ & Spring water \\
\hline S2 & Drilled well 1 & Kifri district & $34.91,44.82$ & Groundwater \\
\hline S3 & Drilled well 2 & Kifri district & $35.02,44.63$ & Groundwater \\
\hline S4 & Water project & Kifri district & $34.70,44.96$ & Surface water - Awaspi river \\
\hline S5 & Drilled well 3 & Kifri district & $34.91,45.07$ & Groundwater \\
\hline S6 & Drilled well 4 & Kifri district & $34.87,44.85$ & Groundwater \\
\hline S7 & Drilled well 5 & Kalar district & $34.64,45.30$ & Groundwater \\
\hline S8 & Water project & Kalar district & $34.65,45.36$ & Surface water - Sirwan River \\
\hline S9 & Drilled well 6 & Kalar district & $34.83,45.51$ & Groundwater \\
\hline S10 & Drilled well 7 & Sarqala, Kifri district & $34.74,45.06$ & Groundwater \\
\hline S11 & Drilled well 8 & Sarqala, Kifri district & $34.74,45.08$ & Groundwater \\
\hline S12 & Drilled well 9 & Rizgari, Kalar district & $34.66,45.26$ & Groundwater \\
\hline S13 & Drilled well 10 & Rizgari, Kalar district & $34.67,45.18$ & Groundwater \\
\hline S14 & Drilled well 11 & Khanaqin district & $34.57,45.35$ & Groundwater \\
\hline S15 & Drilled well 12 & Khanaqin district & $34.39,45.35$ & Groundwater \\
\hline S16 & Water project & Khanaqin district & $34.35,45.39$ & Surface water - Alwand River and Balaju-Cana \\
\hline
\end{tabular}


variation of heavy metal and chemical parameters of water samples. Ward-algorithmic linkage method and Euclidean distance are the basis to conduct statistical cluster analysis. Agglomerative hierarchical clustering is the used statistical cluster analysis. Cluster analysis of water samples was made using XLSTAT (version 2017 for Excel 2013 software).

\subsection{Heavy Metals Pollution Assessment}

\subsubsection{Heavy metal pollution index (HPI)}

In this study, the heavy metal pollution index (HPI) was used with the formula that proposed by Mohan et al. [37]. Where the water quality is assessed according to existence and importance of heavy metals in water samples. Many works have used this index to acquire information on heavy metal pollution potential in tested waters [38]-[41].

HPI is an arithmetical tool that computed on the basis of the arithmetic mean method to transform various water existing data into a single derived number in terms of relevant heavy metals presence effect on water quality.

$$
H P I=\frac{\sum_{i=1}^{n} W_{i} Q_{i}}{\sum_{i=1}^{n} W_{i}}
$$

Where $Q_{i}$ is the subindex of $i$-parameter, $W_{i}$ is the weight of $\mathrm{i}$-parameter, and $\mathrm{n}$ is the total number of parameters that included in test. $W_{i}$ for each parameters is inversely proportional to the recommended standard for the corresponding parameter. The $\mathrm{i}^{\text {th }}$ parameter subindex is calculated as follows.

$Q_{i}=\sum_{i=1}^{n} \frac{\left[M_{i}(-) I_{i}\right]}{\left(S_{i}-I_{i}\right)} * 100$

Where $\mathrm{M}_{\mathrm{i}}, \mathrm{S}_{\mathrm{i}}$, and $\mathrm{I}_{\mathrm{i}}$ are monitored, standard, and ideal values of i-parameter for the investigated heavy metals.

\subsubsection{HEI}

HEI is another pollution index related to heavy metals. Usually, it is applied to get a whole idea on potential water contamination caused by heavy metals. HEI is calculated as following equation [42], [43].

$$
H E I=\sum_{i=1}^{n} \frac{H_{c}}{H_{\text {mac }}}
$$

Where, $\mathrm{H}_{c}$ and $\mathrm{H}_{\operatorname{mac}}$ are the observed and maximum permissible level concentrations for each i-parameter, respectively.
2.5.3. $C_{d}$ The $C_{d}$ is computed to evaluate the contamination of water quality, $\mathrm{C}_{d}$ is a sum of contamination factors of individual parameters those have values above the upper allowable limits [44]. $C_{d}$ takes into consideration the number of parameters exceeding permissible limits and their concentrations [45]. Many works have used this index to reveal any potential contamination and the combined effects of harmful quality parameters in various water resources such as [46] and [47]. $C_{d}$ is calculated as the following two steps.

$$
\begin{aligned}
& C_{d}=\sum_{i=1}^{n} C_{f i} \\
& C_{f i}=\frac{C_{A i}}{C_{N i}}-1
\end{aligned}
$$

Where, $\mathrm{C}_{\mathrm{fi}}, \mathrm{C}_{\mathrm{Ai}}$, and $\mathrm{C}_{\mathrm{Ni}}$ are concentration factor, analytical value, and the upper allowable concentration of the i-parameter, respectively.

\subsection{Methods Evaluation}

Before going any further, it was very necessary to evaluate the performance method applied in this study. The performance evaluation is usually made according to limits of detection (LOD), limit of quantification (LOQ), and linearity [38], [48]. For elements measured by ICPOES, the calibration curves were found depending on the standard addition method. The linearity of the analyzed elements was tested and approved. The LOD and LOQ were estimated per their relations with standard deviation. The accuracy and reproducibility of elements analyzed and measured by ICPOES were determined by spiking and homogenizing three replicates of each of the three samples collected randomly from sampling locations.

\section{RESULTS AND DISCUSSION}

\subsection{Heavy Metals in Drinking Water Samples}

Presence of heavy metals in drinking water samples (groundwater and surface water) from the 16 different sites in Garmian region is illustrated in Tables II and III. In this study, 23 metals of $\mathrm{Cr}, \mathrm{Cu}, \mathrm{Fe}, \mathrm{Mn}, \mathrm{Mo}, \mathrm{Al}, \mathrm{Sr}, \mathrm{Zn}, \mathrm{Ba}$, Se, Li, V, Ni, Cd, As, Pb, Co, Tl, Ag, Be, Hg, Sb, and Sn have been analyzed. Descriptive statics including maximum permissible limit MPL and LOD with the wavelength for the investigated heavy metals at all water sampling locations are presented in Table II. 
As stated in Table II most MPL for the tested parameters are according to the WHO [49] except that MPL for Be, Fe, Mn, Sr, Li, V, Ca, P, Be, Co, Tl, Sn, and T. hardness were adapted from other standards as demonstrated in Table II. From the results obtained, a part of the examined metals of $\mathrm{Ni}, \mathrm{Cd}$, $\mathrm{As}, \mathrm{Pb}, \mathrm{Co}, \mathrm{Tl}, \mathrm{Ag}, \mathrm{Be}, \mathrm{Hg}, \mathrm{Sb}$, and $\mathrm{Sn}$ are not detected due to their concentrations which are below the LOD as shown in Table II. The $\mathrm{pH}$ ranges were from 6.5 to 8.0 for all water samples, with no great difference in $\mathrm{pH}$ values among the sampling locations in which this weak influence could be ignored on the heavy metals presence in tested samples.

From Table II of descriptive statistics, it can be seen from the obtained results that heavy metals characteristics of drinking water quality in Garmian region are generally within acceptable ranges except for $\mathrm{Fe}, \mathrm{Al}, \mathrm{Sr}, \mathrm{Li}$, and $\mathrm{Se}$ at certain locations such as S2, S8, and S14.

The distribution of the measured heavy metals shows that the mean and median values for the metal of aluminum (Al) concentration in water samples $0.3 \mathrm{mg} / \mathrm{L}$ are higher than maximum permissible limits MPL $0.2 \mathrm{mg} / \mathrm{L}$ this reveals the significance of the $\mathrm{Al}$ metal impact on drinking water at those locations in the region. Mean value of lithium $\mathrm{Li}$ is 0.037 which is exceeded MPL at most locations in the study area. Strontium Sr and selenium Se mean values in water samples are 3.838 and $0.038 \mathrm{mg} / \mathrm{L}$ that is close to the maximum permissible limits MPL of 4 , and $0.04 \mathrm{mg} / \mathrm{L}$, respectively, hence this reveals the contribution of Sr and Se in the drop of drinking water quality of the area. The rest of the parameters showed lower concentrations in tested samples.

Table III illustrates more details on heavy metals concentrations among the analyzed drinking water samples that collected from various locations in Garmian Region. The obtained results showed a sign of pollution hazards of certain heavy metals. For $\mathrm{Cr}$ high level it was determined to be $0.021 \mathrm{mg} / \mathrm{L}$ for water samples collected from location $\mathrm{S} 10$ and was low or BDL in the other locations. Cr was only found in groundwater samples $(0.001-0.021 \mathrm{mg} / \mathrm{L})$. In all

TABLE II: Descriptive statistics for heavy metal and chemical parameters in tested water samples

\begin{tabular}{|c|c|c|c|c|c|c|c|c|}
\hline Parameter & Min & Max & Mean & Median & Standard deviation & $\operatorname{LOD}(\mathrm{mg} / \mathrm{L})$ & MPL (mg/L) & Wavelength $(\lambda)$ \\
\hline $\mathrm{Cr}$ & 0.000 & 0.021 & 0.003 & 0.000 & 0.006 & 0.0010 & 0.05 & 267.7 \\
\hline $\mathrm{Cu}$ & 0.011 & 0.028 & 0.018 & 0.016 & 0.005 & 0.0010 & 1 & 324.8 \\
\hline $\mathrm{Fe}$ & 0.009 & 0.736 & 0.074 & 0.0155 & 0.179 & 0.0020 & $0.2^{\mathrm{a}}$ & 259.9 \\
\hline Mo & 0.001 & 0.006 & 0.003 & 0.002 & 0.001 & 0.0010 & $0.07^{b}$ & 202.1 \\
\hline $\mathrm{Al}$ & 0.000 & 0.550 & 0.038 & 0.000 & 0.137 & 0.0040 & $0.1^{\mathrm{b}}$ & 396.2 \\
\hline $\mathrm{Sr}$ & 1.046 & 11.94 & 3.838 & 3.9865 & 2.900 & 0.0020 & $4^{d}$ & 407.7 \\
\hline $\mathrm{Se}$ & 0.027 & 0.044 & 0.038 & 0.038 & 0.004 & 0.0020 & 0.04 & 196.1 \\
\hline $\mathrm{Li}$ & 0.004 & 0.078 & 0.037 & 0.034 & 0.021 & 0.0010 & $0.01^{\mathrm{e}}$ & 670.8 \\
\hline $\mathrm{V}$ & 0.001 & 0.008 & 0.005 & 0.0045 & 0.002 & 0.0025 & $0.015^{f}$ & 292.4 \\
\hline As & $\mathrm{BDL}$ & $\mathrm{BDL}$ & BDL & BDL & -- & 0.0026 & 0.01 & 189.0 \\
\hline $\mathrm{Ag}$ & $\mathrm{BDL}$ & $\mathrm{BDL}$ & $\mathrm{BDL}$ & BDL & -- & 0.0012 & 0.05 & 328.1 \\
\hline $\mathrm{Be}$ & $\mathrm{BDL}$ & $\mathrm{BDL}$ & $\mathrm{BDL}$ & $\mathrm{BDL}$ & -- & 0.0010 & $0.004^{c}$ & 313.1 \\
\hline $\mathrm{Cd}$ & $\mathrm{BDL}$ & $\mathrm{BDL}$ & $\mathrm{BDL}$ & $\mathrm{BDL}$ & -- & 0.0010 & 0.003 & 214.4 \\
\hline $\mathrm{Sb}$ & $\mathrm{BDL}$ & $\mathrm{BDL}$ & $\mathrm{BDL}$ & $\mathrm{BDL}$ & -- & 0.0068 & 0.02 & 206.8 \\
\hline Sn & $\mathrm{BDL}$ & $\mathrm{BDL}$ & $\mathrm{BDL}$ & $\mathrm{BDL}$ & -- & 0.0010 & $0.001^{\mathrm{k}}$ & 190.0 \\
\hline $\mathrm{TI}$ & $\mathrm{BDL}$ & $\mathrm{BDL}$ & $\mathrm{BDL}$ & BDL & -- & 0.0040 & $0.0072^{\mathrm{g}}$ & 190.9 \\
\hline $\mathrm{Ca}$ & 36.48 & 175.41 & 103.55 & 114.54 & 49.22 & 0.004 & $75^{\mathrm{h}}$ & 315.9 \\
\hline $\mathrm{K}$ & 0.78 & 5.04 & 2.24 & 2.16 & 1.24 & 0.031 & $12^{\mathrm{b}}$ & 766.5 \\
\hline $\mathrm{Mg}$ & 9.91 & 69.76 & 37.76 & 47.95 & 20.32 & 0.005 & $50^{\mathrm{b}}$ & 279.1 \\
\hline $\mathrm{Na}$ & 5.34 & 125.53 & 50.59 & 50.09 & 39.86 & 0.066 & 50 & 330.2 \\
\hline$P$ & 0.03 & 0.07 & 0.04 & 0.04 & 0.01 & 0.002 & $0.16^{m}$ & 177.5 \\
\hline T. Hardness & 139.17 & 724.40 & 413.57 & 470.67 & 203.75 & -- & $200^{h}$ & - \\
\hline
\end{tabular}


Hayder Mohammed Issa and Azad H. Alshatteri: Drinking Water Quality of Garmian Region

TABLE III: Concentrations of heavy metals in drinking water samples detected by ICPOES

\begin{tabular}{|c|c|c|c|c|c|c|c|c|c|c|c|c|}
\hline \multirow[t]{2}{*}{ Sample location } & \multicolumn{12}{|c|}{ Concentration (mg/L) } \\
\hline & $\mathrm{Cr}$ & $\mathrm{Cu}$ & $\mathrm{Fe}$ & Mn & Mo & Al & $\mathrm{Sr}$ & $\mathrm{Zn}$ & $\mathrm{Ba}$ & Se & Li & $\mathbf{v}$ \\
\hline $\mathrm{S} 1$ & BDL & 0.021 & 0.009 & 0.001 & 0.002 & BDL & 1.241 & 0.001 & 0.014 & 0.027 & 0.004 & 0.001 \\
\hline S2 & 0.009 & 0.012 & 0.071 & 0.009 & 0.005 & $\mathrm{BDL}$ & 11.940 & 0.386 & 0.006 & 0.042 & 0.075 & 0.005 \\
\hline S4 & BDL & 0.015 & 0.011 & 0.001 & 0.002 & $\mathrm{BDL}$ & 4.398 & 0.020 & 0.015 & 0.038 & 0.047 & 0.004 \\
\hline S5 & $\mathrm{BDL}$ & 0.015 & 0.011 & 0.001 & 0.002 & $\mathrm{BDL}$ & 4.971 & 0.015 & 0.013 & 0.040 & 0.049 & 0.005 \\
\hline S6 & $\mathrm{BDL}$ & 0.013 & 0.013 & 0.001 & 0.001 & BDL & 5.804 & 0.037 & 0.015 & 0.038 & 0.055 & 0.005 \\
\hline S9 & $\mathrm{BDL}$ & 0.022 & 0.012 & 0.001 & 0.001 & BDL & 1.143 & 0.015 & 0.065 & 0.034 & 0.027 & 0.003 \\
\hline $\mathrm{S} 10$ & 0.021 & 0.016 & 0.034 & 0.003 & 0.002 & $\mathrm{BDL}$ & 3.884 & 0.103 & 0.017 & 0.039 & 0.040 & 0.008 \\
\hline $\mathrm{S} 11$ & BDL & 0.023 & 0.014 & 0.001 & 0.004 & BDL & 1.555 & 0.093 & 0.042 & 0.038 & 0.023 & 0.006 \\
\hline $\mathrm{S} 12$ & 0.001 & 0.024 & 0.015 & 0.001 & 0.003 & BDL & 1.601 & 0.006 & 0.045 & 0.034 & 0.019 & 0.007 \\
\hline $\mathrm{S} 13$ & 0.002 & 0.028 & 0.016 & 0.001 & 0.002 & $\mathrm{BDL}$ & 1.046 & 0.001 & 0.056 & 0.034 & 0.011 & 0.008 \\
\hline $\mathrm{S} 14$ & BDL & 0.016 & 0.017 & 0.001 & 0.004 & $\mathrm{BDL}$ & 4.631 & 0.091 & 0.012 & 0.044 & 0.035 & 0.003 \\
\hline
\end{tabular}

sampling locations, low levels of $\mathrm{Cu}$ were detected ranging of $0.011-0.028 \mathrm{mg} / \mathrm{L}$. However, in one location S8 a high level of $\mathrm{Fe} 0.736 \mathrm{mg} / \mathrm{L}$ exceeding the MPL. It was found that the concentrations of $\mathrm{Mn}, \mathrm{Mo}, \mathrm{Zn}, \mathrm{Ba}$, and $\mathrm{V}$ were lower than MPL of $0.05,0.07,3.0,0.7$, and $0.015 \mathrm{mg} / \mathrm{L}$, respectively, in all sampling locations that considered in this study. Zn showed critical concentrations at locations S2 and S10 with the range of 0.386 and $0.103 \mathrm{mg} / \mathrm{L}$. It was noticed at some locations that $\mathrm{Al}, \mathrm{Sr}$, and $\mathrm{Li}$ concentrations are higher than MPL specified by this work. Some heavy metals were not detected in this study in all sampling locations due to their low concentrations levels such as As, $\mathrm{Ag}, \mathrm{Be}, \mathrm{Cd}, \mathrm{Co}, \mathrm{Hg}$, $\mathrm{Ni}, \mathrm{Pb}, \mathrm{Sb}, \mathrm{Sn}$, and Tl. Samples from Diyala-Sirwan River downstream location S8 (Kalar drinking water project was established to provide potable water to Kalar city residents) looks like having higher concentrations than MPL values of $\mathrm{Al}$ and $\mathrm{Fe}$ when compared to groundwater and surface water samples from other locations.

This elevation in $\mathrm{Fe}$ and $\mathrm{Al}$ levels is due to the fact that Diyala-Sirwan River flows through small building materials manufactures. Therefore, the high contamination in this location may come from effluents discharged by these sites and also from aluminum-rich materials used in water treatment. Considerable contaminations of Sr were observed in various locations S1 to S6 and S14 to S16 for both surface and groundwater sources at Khanaqin and Kifri districts. According to USEPA 2008 standards of MPL is $4.0 \mathrm{mg} / 1$ [52], many water samples contain a high level of Sr parameter. These levels are generally related with environmental contamination generated by a natural occurrence of alkaline earth metal. This could be relatively distributed in groundwater as well as in surface water and that is common in such systems and crustal materials [52], [60]. Se and Li levels are high in water samples S2, S3, and S14 for Se and $\mathrm{S} 2, \mathrm{~S} 3$ while the concentration of $\mathrm{Li}$ is $0.055 \mathrm{mg} / \mathrm{L}$ for $\mathrm{S} 6$. High Se and Li levels in certain groundwater samples are occurring due to geogenic sources such as weathering and leaching of rocks, dissolution of soluble salts in soils, and it might occur due to anthropogenic activities [61], [62]. Several chemical parameters of the water quality were investigated in this study. According to their levels and roles in the anthropological life that called macro essential elements, five cations chemical elements were analyzed include $\mathrm{Ca}, \mathrm{K}$, $\mathrm{Mg}, \mathrm{Na}$, and P. The statistical description for these chemical parameters of maximum, minimum, mean, median, and standard deviation for all water samples is summarized in Table II. In many locations, statistics show that the mean and median concentrations are close to or even exceed the MPL. From Tables II and IV, it can be noticed that the ranges of the studied cations of the water samples $(\mathrm{mg} / \mathrm{L})$ were $\mathrm{Ca}$, 36.48-175.4; K, 0.777-5.042; Mg, 9.914-69.757; Na, 5.34125.53; and P, 0.029-0.68; T. Hardness, and 139.171-724.4. $\mathrm{Ca}$ and $\mathrm{Na}$ and $\mathrm{T}$. hardness are in the first class. Magnesium has shown high concentrations in water samples from most locations and exceeded the MPL. High concentrations of Ca and $\mathrm{Mg}$ exist in water samples of Khanaqin district (S14 to S16), Kifri district (S2, S3, S4, S5, S6, and S10), and in one location at Kalar district S7. Accordingly, at these locations, the total hardness is high also. Sources of elevated $\mathrm{Ca}, \mathrm{Na}$, and $\mathrm{Mg}$ ions are more likely to be geogenic, like natural hydro-geochemical processes of soil leaching and chemical weathering of rocks from the adjoining basement complex that causes salinized groundwater and river water [63]. 
Especially in rural areas in the study region, the agricultural runoff has happened on a limited scale. Other anthropogenic activities consequences such as wastewater mixing or leakage have not considerable effects on the groundwater quality. This comes from the fact that no significant human actions present considerable accumulations of chemical elements like cations in water resources at these areas. These variations in cations concentrations are well-known phenomenon, and it has been observed by previous works [64], [65].

\subsection{Statistical Analysis}

A one-way analysis of variance ANOVA function of Excel 2013 was used in this work to validate the significant differences among sampling locations. Statistically analyzed results of water samples using ANOVA were at $95 \%$ confidence level [2].

The variance analysis results showed that all tested heavy metals and chemicals were substantially different at $P<0.05$. $P=0.00722$, F value was 2.187 , and $\mathrm{F}_{\text {crit }}$ was 1.7058 . One-way ANOVA technique was applied in this work because there is only one variable is tested which is the spatial variance of the study area without replication for each sample.

Fig. 2 illustrates the most significant variance of the investigated heavy metals and chemicals in drinking water samples. $\mathrm{Fe}$ and $\mathrm{Al}$ levels showed an interesting deviation at location S8 as mentioned before. Location S8 is a water treatment plant at Kalar City that takes raw water from the nearby Diyala-Sirwan River. This distinction refers to the impact of discharge by the existed construction materials plants situated along the river bank. Similarly, it refers to potential contamination by aluminum-rich material used in water treatment.

Fig. 2 shows high concentrations of particular heavy metals such as $\mathrm{Se}$ and $\mathrm{Sr}$ in most water samples in the study area. As there is no significant anthropogenic activity can cause these elevations in the region. It is assumed that heavy metals come from natural geogenic sources. Ca and Mg levels are high almost all over the study region as presented in Fig. 2. These high levels of $\mathrm{Ca}$ and $\mathrm{Mg}$ are typically caused by geological properties of the region [42]. The CM analysis was performed to figure out the relationships among the water sample contaminants. A correlation coefficient nearer to 1.0 means perfect linear relation between the related parameters. Normally, a correlation coefficient of 1.0 is achieved for parameters related with itself. Table $\mathrm{V}$ illustrates the correlation coefficients matrix between heavy metals and other parameters. Relationships of coefficients $>0.5$ between two investigated parameters at $5 \%$ level of significance and $P<0.05$ are considered significant. Such coefficients were generated between certain pairs of heavy metals or chemical parameters in the water samples.

Strong positive relationships $(>0.7)$ between heavy metals were observed for example (Fe with $\mathrm{Al}$ ), (Li with $\mathrm{Sr}$ and $\mathrm{Se}$ ). At the same time, strong negative relationships $(<0.8)$ were found such as ( $\mathrm{Sr}$ with $\mathrm{Cu})$, and $(\mathrm{Cu}$ with $\mathrm{Li})$. Correlations at $P<0.05$ were obtained for the tested heavy metals and chemical parameters. There were significant positive correlations between $\mathrm{Se}, \mathrm{Li}$, and $\mathrm{Sr}$ with all tested chemical parameters in this study except P. Furthermore, significant negative correlations exist between $\mathrm{Cu}$ with all tested chemical parameters in this study except $\mathrm{P}$.

\section{Table IV: Concentrations of chemical parameters in water samples}

\begin{tabular}{|c|c|c|c|c|c|c|}
\hline \multirow[t]{2}{*}{ Sample location } & \multicolumn{6}{|c|}{ Concentration (mg/L) } \\
\hline & $\mathrm{Ca}$ & $\mathbf{K}$ & Mg & $\mathrm{Na}$ & $\mathbf{P}$ & T. Hardness \\
\hline S1 & 36.484 & 0.777 & 14.811 & 5.340 & 0.043 & 151.816 \\
\hline $\mathrm{S} 2$ & 141.971 & 2.649 & 47.825 & 79.775 & 0.029 & 551.01 \\
\hline S3 & 139.498 & 4.640 & 48.077 & 125.530 & 0.032 & 545.86 \\
\hline S4 & 135.276 & 2.591 & 48.693 & 59.302 & 0.037 & 537.712 \\
\hline S5 & 138.011 & 2.661 & 48.867 & 58.618 & 0.036 & 545.263 \\
\hline S6 & 157.008 & 2.998 & 61.069 & 66.198 & 0.034 & 642.784 \\
\hline S7 & 93.794 & 1.461 & 23.024 & 15.805 & 0.040 & 328.765 \\
\hline S8 & 59.108 & 2.396 & 17.636 & 14.340 & 0.054 & 219.959 \\
\hline S9 & 60.182 & 1.244 & 16.340 & 9.985 & 0.048 & 217.330 \\
\hline S10 & 81.322 & 1.932 & 48.889 & 112.068 & 0.039 & 403.631 \\
\hline S11 & 48.927 & 1.054 & 18.055 & 15.993 & 0.049 & 196.224 \\
\hline S12 & 50.530 & 1.081 & 16.222 & 17.907 & 0.065 & 192.716 \\
\hline S13 & 39.457 & 1.028 & 9.914 & 15.094 & 0.068 & 139.171 \\
\hline S14 & 139.603 & 1.765 & 52.928 & 41.571 & 0.039 & 565.893 \\
\hline S15 & 160.174 & 2.528 & 62.035 & 64.985 & 0.036 & 654.660 \\
\hline S16 & 175.406 & 5.042 & 69.757 & 106.877 & 0.045 & 724.400 \\
\hline
\end{tabular}


Hayder Mohammed Issa and Azad H. Alshatteri: Drinking Water Quality of Garmian Region

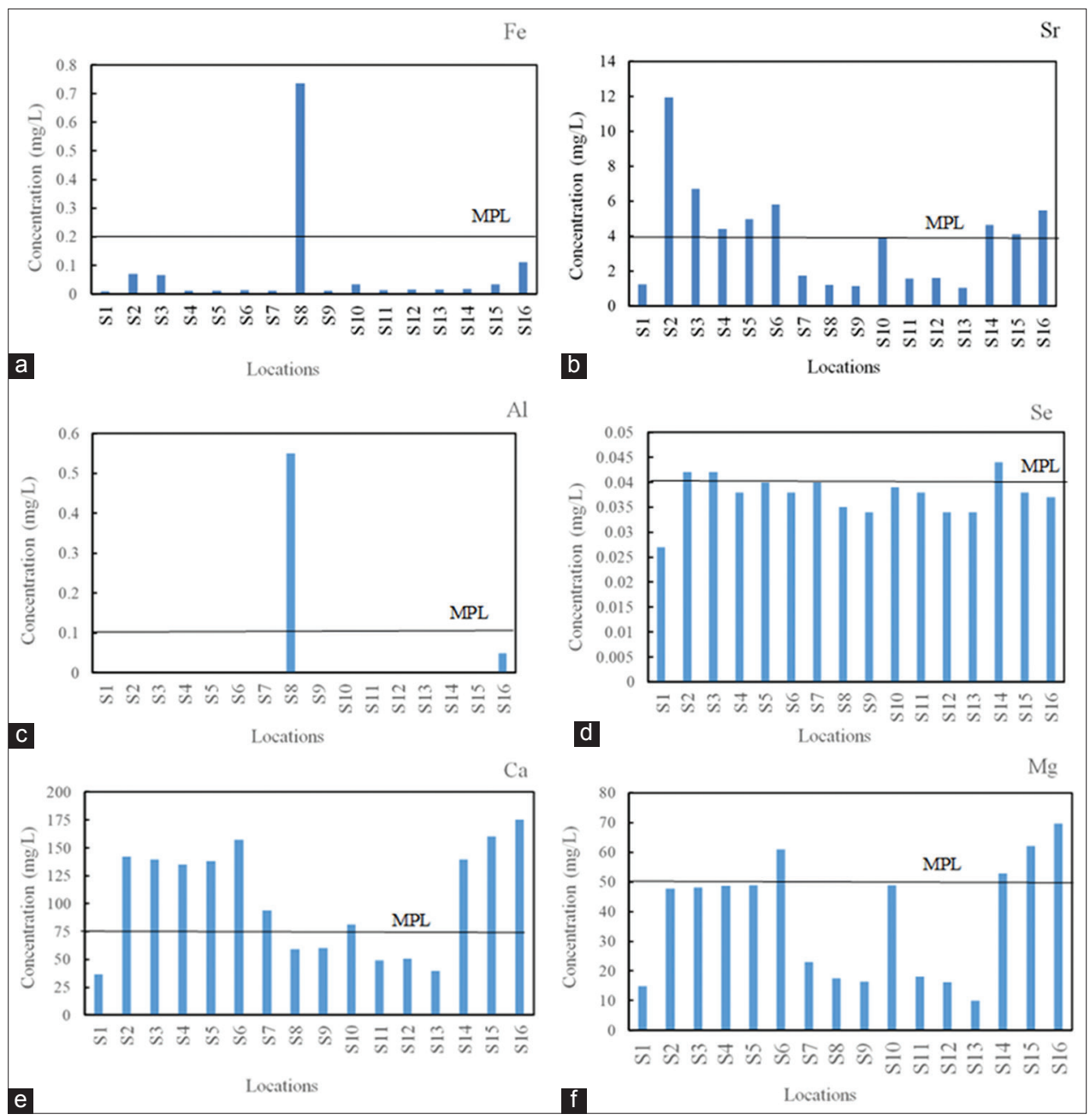

Fig. 2. Mean concentrations spatial distribution for some heavy metals and chemical parameters with indicating MPL limit; (a) for iron, (b) for strontium, (c) for aluminum, (d) for selenium, (e) for calcium, and (f) for magnesium.

These significant correlations confirm the source of the heavy metals and chemical parameters in water samples are the geological structure or composition of rocks, soil. Heavy metals enrichment of $\mathrm{Al}$ and $\mathrm{Fe}$ in the water sample $\mathrm{S} 8$ is attributed to small projects constructed beside Diyala-Sirwan River, as most the effluents are washed by surface runoff and goes into the river. Aluminum-rich materials utilized on the site of the water treatment plant could be the second source of $\mathrm{Al}[66]$.

\subsubsection{Cluster analysis}

The CA analysis can identify any similarity that exists among clustered results. By showing considerable internal clusters homogeneity and significant external heterogeneity concerning clusters. Hierarchical agglomerative clustering is applied to find any spatial similarity between water samples regarding their locations in the study area.
From the results illustrated in Fig. 3, the dendrogram of hierarchical cluster analysis has generated three distinct clusters. A similarity of water samples in term of sampling locations are classified into three principal cluster groups.

The main groups of sample locations are Cluster 1, contains sampling locations of S2, S3, and S4, S5, S6, S10, S14, S15, and S16. Cluster 2, includes one sampling location of S8. Cluster 3, combines sampling locations of S1, S7, S9, S11, $\mathrm{S} 12$, and $\mathrm{S} 13$.

It can be deduced from the cluster analysis that the spatial division was based principally on the type of heavy metals contamination. As the location S8 in Cluster 2 is a water treatment plant constructed at downstream of a river, this sample showed different contamination (high levels of Fe and 
TABLE V: Correlation matrix between heavy metals and chemical parameters in analyzed water samples

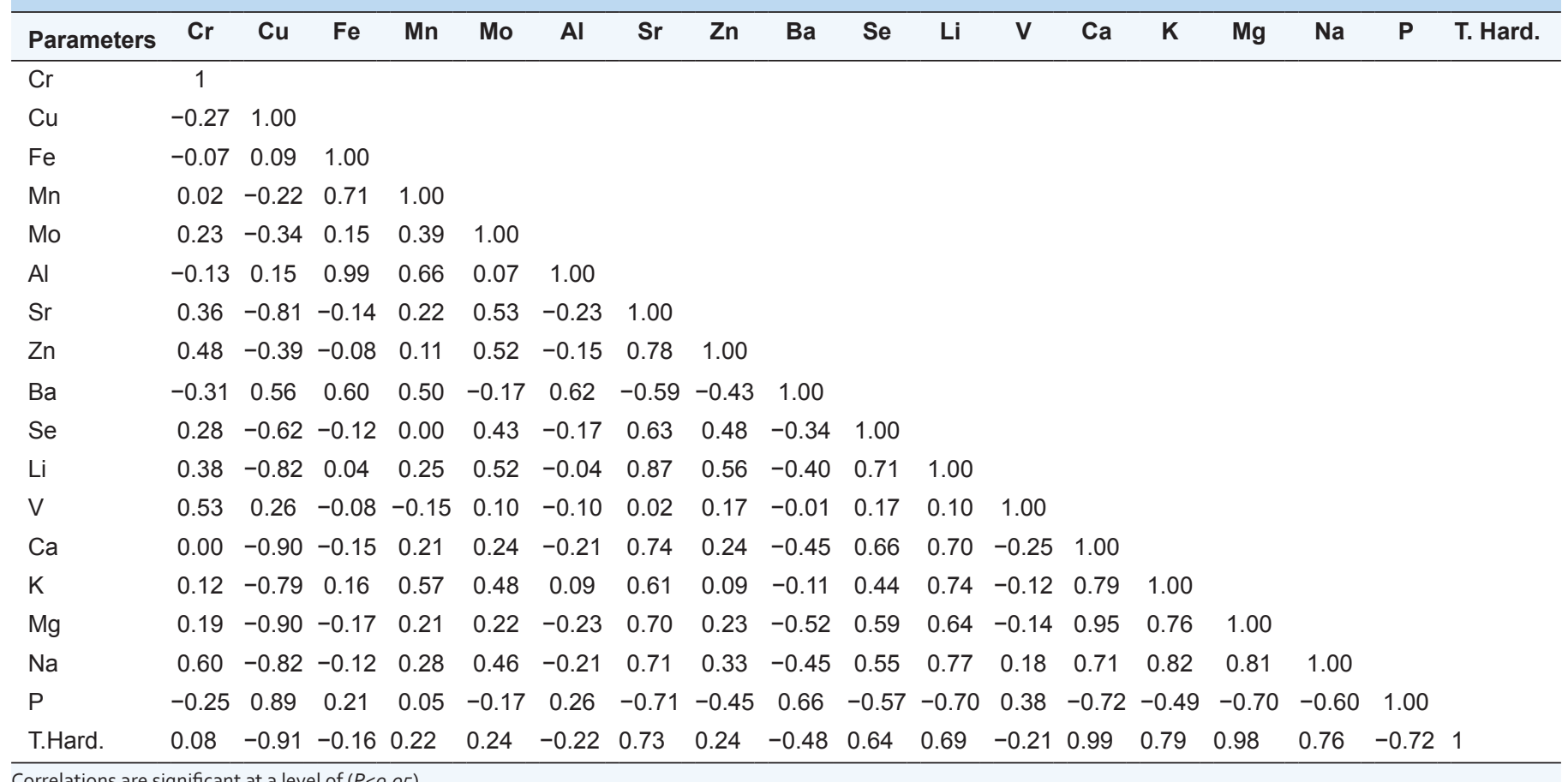

Correlations are significant at a level of $(P<0.05)$

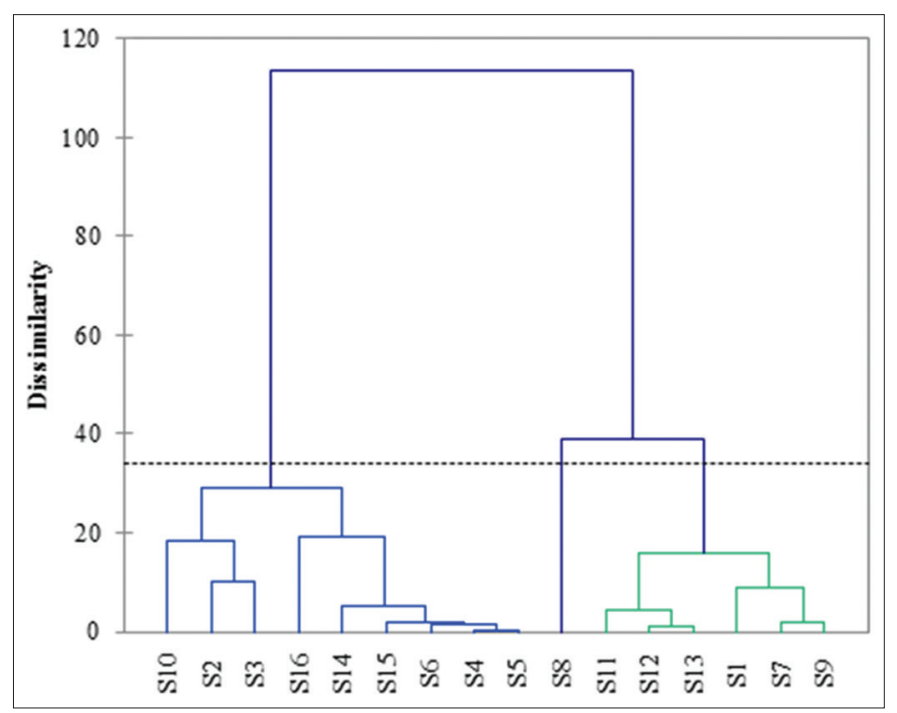

Fig. 3. Hierarchical cluster analysis dendrogram of water samples locations.

Al) from other locations. In Cluster 3, groundwater samples were of low concentrations of heavy metals.

\subsubsection{Contamination evaluation indices}

Contamination evaluation indices HPI, HEI, and $\mathrm{C}_{\mathrm{d}}$ in this work based on the WHO guidelines for drinking water and other standards taken from the literature. Mean values of the heavy metals were used to calculate contamination evaluation indices HPI and HEI while mean values of heavy metals and chemical parameters were used to calculate contamination degree index $C_{d}$.

Table VI illustrates the values of HPI, HEI, and $\mathrm{C}_{\mathrm{d}}$. HPI for the heavy metals in water samples ranges from 54.986 to 24.564 with a mean value of 25.48 . Location S8 has the highest HPI value. HPI value equals 100 is considered as a critical potential pollution with respect to heavy metals concentrations [41].

No location in the study area has exceeded this limit. Nevertheless, as stated by Herojeet et al. [67] HPI results were classified as low (<15), medium (15-30), or high $(>30)$ pollution. In this case, only two locations (S1 and S16) are not highly contaminated by heavy metals.

It is worth mentioning here; highest HPI value comes from water treatment plant at Kalar City that takes raw water from Diyala - Sirwan River. The elevated HPI at this site is in accord with the statistical analysis results. High HPI is due to the impact of the building material plants at a river bank.

Otherwise, it caused by materials used in water treatment. Other groundwater samples have also registered high HPI values at locations S10 and S13, where the heavy metal

UHD Journal of Science and Technology | May 2018 | Vol 2 | Issue 2 
pollution comes from natural sources and much less from domestic waste and agricultural runoff.

The lowest HPI recorded in the study region was for the water sample S1, S1 which is a spring water located at north of the region and no anthropogenic pollution exist.

Table VII depicts the deviation and percentage deviation from mean values for HPI, HEI, and $\mathrm{C}_{d}$ indices. From Table

\section{TABLE VI: Values of pollution indices}

\begin{tabular}{lccc}
\hline Sample location & HPI & HEI & Cd \\
\hline S1 & 24.564 & 1.179 & -14.839 \\
S2 & 39.425 & 5.298 & -5.100 \\
S3 & 41.324 & 3.817 & -5.534 \\
S4 & 37.348 & 2.485 & -8.416 \\
S5 & 40.949 & 2.743 & -8.095 \\
S6 & 40.009 & 2.907 & -6.778 \\
S7 & 35.160 & 1.840 & -12.117 \\
S8 & 54.986 & 8.441 & -6.495 \\
S9 & 32.750 & 1.556 & -13.625 \\
S10 & 52.622 & 3.238 & -8.035 \\
S11 & 43.015 & 1.992 & -13.300 \\
S12 & 44.334 & 1.965 & -13.218 \\
S13 & 47.210 & 1.915 & -13.852 \\
S14 & 36.981 & 2.687 & -8.341 \\
S15 & 33.811 & 2.445 & -7.170 \\
S16 & 29.678 & 3.886 & -3.920 \\
Mean & 39.635 & 3.023 & -9.302 \\
Standard deviation & 7.916 & 1.773 & 3.593 \\
Min. & 24.564 & 1.179 & -14.839 \\
Max. & 54.986 & 8.441 & -3.920 \\
\hline
\end{tabular}

HPI: Heavy metals pollution index, HEI: Heavy metals evaluation index, $C_{d}$ : Contamination index
VII, it is noticed that eight locations ( $\mathrm{S} 3, \mathrm{~S} 5, \mathrm{~S} 6, \mathrm{~S} 8, \mathrm{~S} 10, \mathrm{~S} 11$, S12, and S13) have HPI values above the HPI mean value. In other words, it can be said that $50 \%$ of the study area is significantly affected by heavy metals pollution in drinking water sources according to the HPI index.

The classification of overall drinking water quality per HEI is low $(<1.24)$, medium $(1.24-2.48)$ and high $(>2.48)$ polluted [68]. The quality of drinking water in regard to HEI at the majority of sampling locations (S2, S3, S4, S5, S6, S8, S10, A14, and S16) is in the high class (HEI > 2.45). The water resources in these locations are surface water and groundwater. Elevated heavy metals concentrations are observed in certain water samples.

The maximum HEI value is 8.441 for the location S8. Location S8 has also the highest HPI value; the reason for the rise is mentioned previously. Substantially, the lowest HEI value of 1.179 for surface water sample from the location S1, considering all sampling locations. Water source at this location is spring water; hence, it is the less contaminated site in the study area.

Table VII shows that only five locations (S2, S3, S8, S10, and S16) have HEI values above the mean value. Their percentage of deviation from HEI mean value ranges from $7.07 \%$ at S8 to $179.07 \%$ at S10. By considering HEI results, among the highest five polluted locations; two of them are surface water of S8 and S16.

TABLE VII: Mean deviation values of contamination indices

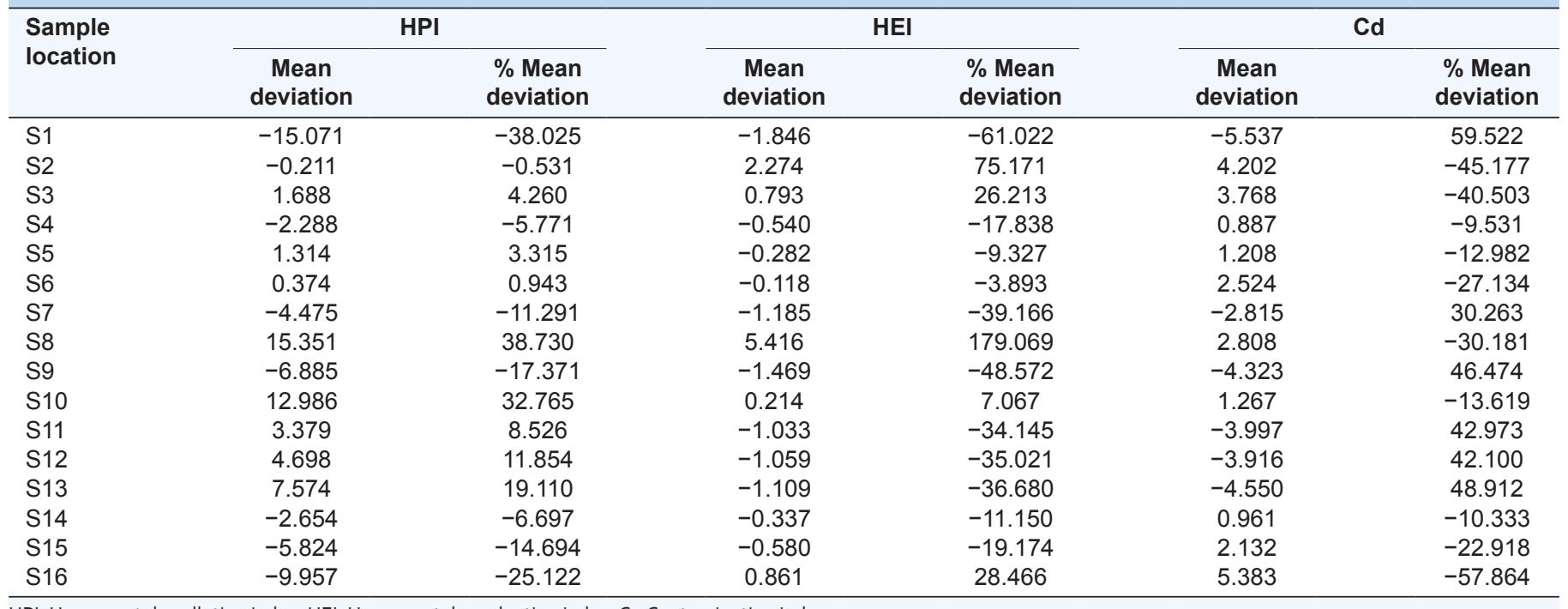

HPI: Heavy metals pollution index, HEI: Heavy metals evaluation index, $\mathrm{C}_{\mathrm{d}}$ : Contamination index 
A difference between HPI and HEI results appears pursuant to divergence in results at several locations see Fig. 4. This great variation was increased by taking in account ideal values of permissible limits of heavy metals with HPI calculations. These permissible limits are subject to variations according to different accredited authorities.

All measured parameters were implied: The heavy metals and chemical parameters. Characterizing $\mathrm{C}_{\mathrm{d}}$ values were made as previous works. $C_{d}$ was classified into three groups: Low $\left(C_{d}<1\right)$, medium $\left(C_{d}=1-3\right)$, and high $\left(C_{d}\right.$ $>3$ ) [44], [69], [70]. $C_{d}$ results range between -14.839 and -3.920 . The mean value is -9.302 , with $>60 \%$ of water samples falling above the mean value. Percentage of deviation from mean value ranges from $57.86 \%$ at S16 to $9.53 \%$ at S4 (Table VII). The previously proposed classification of $\mathrm{C}_{\mathrm{d}}$ consider all water samples (surface water and groundwater) are low; as they did not exceed 1.0. Therefore, the study area is considered as slightly polluted with respect to all pollutants (heavy metals and chemical). From Fig. 4, the results of $\mathrm{C}_{d}$ show a convergence with HEI results. The two indices did not take into account the ideal limits for tested parameters. Different evaluations were observed between HEI and $\mathrm{C}_{\mathrm{d}}$. The differences were rising from the fact that $C_{d}$ is combining the chemical parameters in the pollution assessment calculations. The obtained results led to figuring out the impact of the heavy metals on the drinking water quality in Garmian Region. The contamination is due to the nature of the soil and underlying rocks compositions. Weathering and leaching of soluble salts from the soil and underlying rocks may reach the water resource in the region. Anthropogenic activities impact was observed in water quality in the results of HPI, HEI, and $C_{d}$ for the location S8 particularly the minor industrial activities near Diyala-Sirwan River.

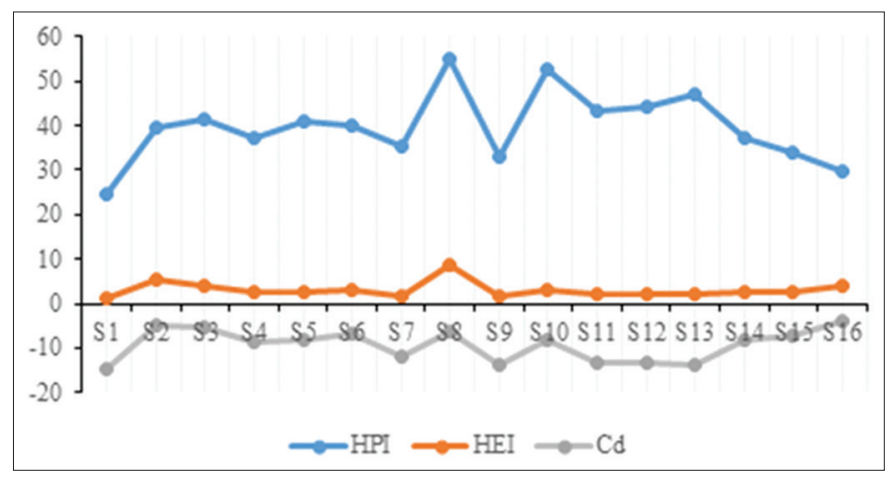

Fig. 4. Spatial distribution of heavy metals pollution index, heavy metals evaluation index, and contamination index on sampling locations of study area.

\section{CONCLUSION}

- In this work, the used statistical methods were: $\mathrm{CM}$ and cluster analysis CA. The obtained results showed that the drinking water quality in most locations of the study area is polluted at different levels.

- Concentrations of some heavy metals such as Fe, Al, Li, $\mathrm{Sr}$, and Se are considerably high at certain locations in the study area. For example location S8, which is the water treatment plant of Kalar City recorded the highest levels of $\mathrm{Al}$ and $\mathrm{Fe}$. Correspondingly, chemical parameters concentrations of $\mathrm{Ca}$ and $\mathrm{Mg}$ are high in most the tested water samples in the study area.

- In general, water pollution indices, HPI, HEI, and $\mathrm{Cd}$ have provided an overview of the extent of contamination at all locations in the Garmian area. For most of these locations, pollution indices have made a convergent evaluation and their values showed considerable correlation. Nevertheless, three extreme results have appeared in the locations S14, S15, and S16 of HPI with HEI and Cd. The variances in these locations are most likely due to differences in the heavy metals concentrations assessment schemes used by HPI. According to HPI contamination evaluation level, all the investigated locations are not critically polluted in view of the fact that HPI is $<100$ as proposed by Prasad and Bose [41]. Where the HPI is between 24.564 and 54.986. According to $\mathrm{Cd}$, all study locations are occurred within low polluted level $\mathrm{Cd}$ index places all the locations within low polluted levels $(\mathrm{Cd}>3$ for all the study area). The third pollution evaluation index HEI has a more reliable pollution categorization for water samples, in which low (<1.24), medium (1.24-2.48), and high (>2.48). As per HEI evaluation levels, $44 \%$ of location is critically polluted and $38 \%$ of the locations are moderately polluted. All surface water samples S4, S8, and S16 are classified as critically polluted, where the highest level of contamination was observed at location S8 (HEI = 8.441). Hence, HEI proved to be more appropriate for heavy metal pollution evaluation, as the unwieldy way of calculation processed by $\mathrm{Cd}$ and HPI.

- Statistical analysis by correlation coefficient matrix and cluster analysis CA was applied in the study. These methods detected that heavy metals and other contaminants in drinking water are mostly released from natural geological sources. Especially, weathering and leaching of soils and underlain rocks. While anthropogenic activities sources were only found in the locations S8 and S16. The CA and $\mathrm{CM}$ analytical results gave a concrete agreement between them for all the data sets investigated. 
- Drinking water samples studied in this work are the main source for residents living in rural and urban locations of Garmian Region. Detection of high or critical levels in collected samples means there is a significant potential for drinking water contamination by heavy metals in the area. Hence, this study leads to establish a reliable database on heavy metals and their potential sources that leaching into the water resources of Garmian Region. These findings give a rigid base for any further studies performed on the drinking water quality in same area to reach a broad understanding of natural and anthropogenic impacts on drinking water quality in Garmian region. The importance of comparative evaluation by HPI and statistical methods is proved to be significant in such water quality studies.

\section{REFERENCES}

[1] H. Effendi. "River water quality preliminary rapid assessment using pollution index". Procedia Environmental Sciences, vol. 33, pp. 562-567, 2016.

[2] A. Z. Aris, R. C. Y. Kam, A. P. Lim and S. M. Praveena. "Concentration of ions in selected bottled water samples sold in Malaysia". Applied Water Science, vol. 3, pp. 67-75, 2013.

[3] D. K. Gupta and L. M. Sandalio, Metal Toxicity in Plants: Perception, Signaling and Remediation. Springer, Berlin Heidelberg, 2011.

[4] J. E. Marcovecchio, S. E. Botté, and R. H. Freije. "Heavy metals, major metals, trace elements". Handbook of Water Analysis, vol. 2, pp. 275-311, 2007.

[5] N. A. Nkono and O. I. Asubiojo. "Trace elements in bottled and soft drinks in Nigeria - A preliminary study". Science of the Total Environment, vol. 208, pp. 161-163, 1997.

[6] J. Duruibe, M. Ogwuegbu and J. Egwurugwu. "Heavy metal pollution and human biotoxic effects". International Journal of Physical Sciences, vol. 2, pp. 112-118, 2007.

[7] M. S. Nahar and J. Zhang. "Assessment of potable water quality including organic, inorganic, and trace metal concentrations". Environmental Geochemistry and Health, vol. 34, pp. 141-150, 2012.

[8] Y. Meride and B. Ayenew. "Drinking water quality assessment and its effects on residents health in Wondo genet campus, Ethiopia". Environmental Systems Research, vol. 5, p. 1, 2016.

[9] R. Peiravi, H. Alidadi, A. A. Dehghan and M. Vahedian. "Heavy metals concentrations in mashhad drinking water network". Zahedan Journal of Research in Medical Sciences, vol. 15, pp. 7476, 2013.

[10] C. Güler. "Evaluation of maximum contaminant levels in Turkish bottled drinking waters utilizing parameters reported on manufacturer's labeling and government-issued production licenses". Journal of Food Composition and Analysis, vol. 20, pp. 262-272, 2007.

[11] G. Tamasi and R. Cini. "Heavy metals in drinking waters from Mount Amiata (Tuscany, Italy). Possible risks from arsenic for public health in the Province of Siena". Science of The Total Environment, vol. 327, pp. 41-51, 2004.

[12] Z. Napacho and S. Manyele. "Quality assessment of drinking water in Temeke District (part II): Characterization of chemical parameters". African Journal of Environmental Science and Technology, vol. 4, pp. 775-789, 2010.

[13] R. Virha, A. K. Biswas, V. K. Kakaria, T. A. Qureshi, K. Borana and N. Malik. "Seasonal variation in physicochemical parameters and heavy metals in water of upper lake of Bhopal". Bulletin of Environmental Contamination and Toxicology, vol. 86, pp. 168174, 2011.

[14] V. Demir, T. Dere, S. Ergin, Y. Cakır and F. Celik. "Determination and health risk assessment of heavy metals in drinking water of Tunceli, Turkey". Water Resources, vol. 42, pp. 508-516, 2015.

[15] D. D. Runnells, T. A. Shepherd and E. E. Angino. "Metals in water. Determining natural background concentrations in mineralized areas". Environmental Science and Technology, vol. 26, pp. 23162323, 1992.

[16] B. Nadmitov, S. Hong, S. In Kang, J. M. Chu, B. Gomboev, L. Janchivdorj, C. H. Lee and J. S. Khim. "Large-scale monitoring and assessment of metal contamination in surface water of the Selenga River Basin (2007-2009)". Environmental Science and Pollution Research, vol. 22, pp. 2856-2867, 2015.

[17] J. Milivojević, D. Krstić, B. Šmit and V. Djekić. "Assessment of heavy metal contamination and calculation of its pollution index for uglješnica river, Serbia". Bulletin of Environmental Contamination and Toxicology, vol. 97, pp. 737-742, 2016.

[18] S. Mishra, A. Kumar, S. Yadav and M. K. Singhal. "Assessment of heavy metal contamination in water of Kali River using principle component and cluster analysis, India". Sustainable Water Resources Management, vol. 21, pp. 515-532, 2017.

[19] B. Backman, D. Bodiš, P. Lahermo, S. Rapant and T. Tarvainen. "Application of a groundwater contamination index in Finland and Slovakia". Environmental Geology, vol. 36, pp. 55-64, 1998.

[20] R. O. Rasheed and U. M. K. Aziz. "Evaluation of some heavy metals in well water within sulaimani city, Kurdistan Region-Iraq". Marsh Bulletin, vol. 8, pp. 131-147, 2013.

[21] W. S. Kamil and K. A. Abdulrazzaq. "Construction water suitability maps of tigris river for irrigation and drinking use". Journal of Engineering-Iraq, vol. 16, pp. 5822-5841, 2010.

[22] M. A. Ibrahim. "Assessment of water quality status for the euphrates river in Iraq". Engineering and Technology Journal, vol. 30, pp. 2536-2549, 2012.

[23] H. M. Issa. "An initial environmental assessment for the potential risk of the developing industry impact on the surface water resources in the kurdistan region-Iraq". Journal of Garmian University, vol. 1, pp. 35-48, 2014.

[24] N. Kharrufa. "Simplified equation for evapotranspiration in arid regions". Beiträge Zur Hydrologie, vol. 5, pp. 39-47, 1985.

[25] A. S. Muhaimeed, A. Saloom, K. Saleim and K. Alaane. Classification and distribution of Iraqi soils". International Journal of Agriculture Innovations and Research, vol. 2, pp. 997-1002, 2014.

[26] S. Jassim and J. Goff. "Geology of Iraq. Dolin, prague and moravian museum”. Brno, vol. 2006, p. 341, 2006.

[27] S. N. Azeez and I. Rahimi. "Distribution of gypsiferous soil using geoinformatics techniques for some aridisols in garmian, Kurdistan Region-Iraq". Kurdistan Journal of Applied Research, vol. 2, pp. 57-64, 2017.

[28] S. M. Ali and A. S. Oleiwi. "Modelling of groundwater flow of Khanaqin Area, Northeast Iraq". Iraqi Bulletin of Geology and Mining, vol. 11, pp. 83-94, 2015.

[29] E. Z. Jahromi, A. Bidari, Y. Assadi, M. R. M. Hosseini and M. R. Jamali. "Dispersive liquid-liquid microextraction combined with graphite furnace atomic absorption spectrometry: Ultra trace 
determination of cadmium in water samples". Analytica Chimica Acta, vol. 585, pp. 305-311, 2007.

[30] J. Chen and K. C. Teo. "Determination of cadmium, copper, lead and zinc in water samples by flame atomic absorption spectrometry after cloud point extraction". Analytica Chimica Acta, vol. 450, pp. 215-222, 2001.

[31] O. V. S. Raju, P. Prasad, V. Varalakshmi and Y. R. Reddy. "Determination of heavy metals in ground water by icp-oes in selected coastal area of spsr nellore District, Andhra Pradesh, India". International Journal of Innovative Research in Science, Engineering and Technology, vol. 3, pp. 9745-9749, 2014.

[32] E. L. Silva, P. D. S. Roldan and M. F. Giné. "Simultaneous preconcentration of copper, zinc, cadmium, and nickel in water samples by cloud point extraction using 4-(2-pyridylazo)-resorcinol and their determination by inductively coupled plasma optic emission spectrometry". Journal of Hazardous Materials, vol. 171, pp. 1133-1138, 2009.

[33] P. Liang, Y. Qin, B. Hu, T. Peng and Z. Jiang. "Nanometer-size titanium dioxide microcolumn on-line preconcentration of trace metals and their determination by inductively coupled plasma atomic emission spectrometry in water". Analytica Chimica Acta, vol. 440, pp. 207-213, 2001.

[34] I. Komorowicz and D. Barałkiewicz. "Arsenic and its speciation in water samples by high performance liquid chromatography inductively coupled plasma mass spectrometry-last decade review". Talanta, vol. 84, pp. 247-261, 2011.

[35] A. Ali, V. Strezov, P. Davies and I. Wright. "Environmental impact of coal mining and coal seam gas production on surface water quality in the Sydney basin, Australia". Environmental Monitoring and Assessment, vol. 189, p. 408, 2017.

[36] K. H. Low, I. B. Koki, H. Juahir, A. Azid, S. Behkami, R. Ikram, H. A. Mohammed and S. M. Zain". Evaluation of water quality variation in lakes, rivers, and ex-mining ponds in Malaysia (review)". Desalination and Water Treatment, vol. 57, pp. 28215-28239, 2016.

[37] S. V. Mohan, P. Nithila and S. J. Reddy. "Estimation of heavy metals in drinking water and development of heavy metal pollution index". Journal of Environmental Science and Health Part A, vol. 31, pp. 283-289, 1996.

[38] M. F. Cengiz, S. Kilic, F. Yalcin, M. Kilic and M. G. Yalcin. "Evaluation of heavy metal risk potential in Bogacayi River water (Antalya, Turkey)". Environmental Monitoring and Assessment, vol. 189, p. 248, 2017.

[39] B. A. Zakhem and R. Hafez. "Heavy metal pollution index for groundwater quality assessment in Damascus Oasis, Syria". Environmental Earth Sciences, vol. 73, pp. 6591-6600, 2015.

[40] R. Reza and G. Singh. "Heavy metal contamination and its indexing approach for river water". International Journal of Environmental Science and Technology, vol. 7, pp. 785-792, 2010.

[41] B. Prasad and J. Bose. "Evaluation of the heavy metal pollution index for surface and spring water near a limestone mining area of the lower Himalayas" Environmental Geology, vol. 41, pp. 183188, 2001.

[42] T. K. Boateng, F. Opoku, S. O. Acquaah and O. Akoto. "Pollution evaluation, sources and risk assessment of heavy metals in handdug wells from Ejisu-Juaben Municipality, Ghana". Environmental Systems Research, vol. 4, p. 18, 2015.

[43] C. Singaraja, S. Chidambaram, K. Srinivasamoorthy, P. Anandhan and S. Selvam. "A study on assessment of credible sources of heavy metal pollution vulnerability in groundwater of Thoothukudi districts, Tamilnadu, India". Water Quality, Exposure and Health, vol. 7, pp. 459-467, 2015.

[44] A. Edet and O. Offiong. "Evaluation of water quality pollution indices for heavy metal contamination monitoring. A study case from Akpabuyo-Odukpani area, Lower Cross River Basin (southeastern Nigeria)". Geo Journal, vol. 57, pp. 295-304, 2002.

[45] S. Venkatramanan, S. Y. Chung, T. H. Kim, M. V. Prasanna and S. Y. Hamm. "Assessment and distribution of metals contamination in groundwater: A case study of busan City, Korea". Water Quality, Exposure and Health, vol. 7, pp. 219-225, 2015.

[46] M. A. Bhuiyan, M. Islam, S. B. Dampare, L. Parvez and S. Suzuki. "Evaluation of hazardous metal pollution in irrigation and drinking water systems in the vicinity of a coal mine area of northwestern Bangladesh". Journal of Hazardous Materials, vol. 179, pp. 10651077, 2010.

[47] J. Varghese and D. S. Jaya. "Metal pollution of groundwater in the vicinity of valiathura sewage farm in Kerala, South India". Bulletin of Environmental Contamination and Toxicology, vol. 93, pp. 694698, 2014.

[48] S. J. Cobbina, A. B. Duwiejuah, R. Quansah, S. Obiri and N. Bakobie. "Comparative assessment of heavy metals in drinking water sources in two small-scale mining communities in northern Ghana". International Journal of Environmental Research and Public Health, vol. 12, pp. 10620-10634, 2015.

[49] World Health Organization. Guidelines for Drinking-water Quality. WHO Publications, 2011.

[50] M. Prasanna, S. Praveena, S. Chidambaram, R. Nagarajan and A. Elayaraja. "Evaluation of water quality pollution indices for heavy metal contamination monitoring: A case study from Curtin Lake, Miri City, East Malaysia". Environmental Earth Sciences, vol. 67, pp. 1987-2001, 2012.

[51] A. Alsulaili, M. Al-Harbi and K. Al-Tawari. "Physical and chemical characteristics of drinking water quality in Kuwait: Tap vs. bottled water". Journal of Engineering Research, vol. 3, pp. 25-50, 2015.

[52] A. J. O'Donnell, D. A. Lytle, S. Harmon, K. Vu, H. Chait and D. D. Dionysiou. "Removal of strontium from drinking water by conventional treatment and lime softening in bench-scale studies". Water Research, vol. 103, pp. 319-333, 2016.

[53] L. A. Kszos and A. J. Stewart. "Review of lithium in the aquatic environment: Distribution in the United States, toxicity and case example of groundwater contamination". Ecotoxicology, vol. 12, pp. 439-447, 2003.

[54] T. L. Gerke, K. G. Scheckel and J. B. Maynard. "Speciation and distribution of vanadium in drinking water iron pipe corrosion byproducts". Science of the Total Environment, vol. 408, pp. 58455853, 2010.

[55] M. Gedrekidan and Z. Samuel. "Concentration of heavy metals in drinking water from urban areas of the tigray region, Northern Ethiopia". CNCS Mekelle University, vol. 3, pp. 105-121, 2011.

[56] A. J. Peter and T. Viraraghavan. "Thallium: A review of public health and environmental concerns". Environment International, vol. 31, pp. 493-501, 2005.

[57] A. Akpan-Idiok, A. Ibrahim and I. Udo. "Water quality assessment of okpauku river for drinking and irrigation uses in Yala, Cross river state, Nigeria". Research Journal of Environmental Sciences, vol. 6, p. 210, 2012.

[58] Safe Drinking Water Committee. Drinking Water and Health. $8^{\text {th }}$ ed. National Acadamey of Sciences, USA, 1988.

[59] $\mathrm{H}$. Boyacioglu. Development of a water quality index based on a European classification scheme". Water Sa, vol. 33, pp. 389-393, 2007. 
[60] V. Achal, X. Pan and D. Zhang. "Bioremediation of strontium (Sr) contaminated aquifer quartz sand based on carbonate precipitation induced by $\mathrm{Sr}$ resistant Halomonas sp". Chemosphere, vol. 89, pp. 764-768, 2012.

[61] A. R. Kumar and P. Riyazuddin. "Speciation of selenium in groundwater: Seasonal variations and redox transformations". Journal of Hazardous Materials, vol. 192, pp. 263-269, 2011.

[62] J. F. Hogan and J. D. Blum. "Boron and lithium isotopes as groundwater tracers: A study at the Fresh Kills Landfill, Staten Island, New York, USA". Applied Geochemistry, vol. 18, pp. 615627, 2003.

[63] M. A. H. Bhuiyan, M. Bodrud-Doza, A. R. M. T. Islam, M. A. Rakib, M. S. Rahman and A. L. Ramanathan. "Assessment of groundwater quality of Lakshimpur district of Bangladesh using water quality indices, geostatistical methods, and multivariate analysis". Environmental Earth Sciences, vol. 75, p. 1020, 2016.

[64] D. A. Al-Manmi. "Groundwater quality evaluation in KalarTownSulaimani/NE-Iraq". Iraqi National Journal of Earth Sciences, vol. 7, pp. 31-52, 2007.

[65] A. H. Alshatteri, A. R. Sarhat and A. M. Jaff. "Assessment of sirwan river water quality from downstream of darbandikhan dam to kalar District, Kurdistan Region, Iraq. Journal of Garmian University, vol. 5, pp. 48-58, 2018.

[66] H. M. Issa. Evaluation of water quality and performance for a water treatment plant: Khanaqin city as a case study. Journal of Garmian University, vol. 3, pp. 802-821, 2017.

[67] R. Herojeet, M. S. Rishi and N. Kishore. "Integrated approach of heavy metal pollution indices and complexity quantification using chemometric models in the Sirsa Basin, Nalagarh valley, Himachal Pradesh, India". Chinese Journal of Geochemistry, vol. 34, pp. 620633, 2015.

[68] Z. Khoshnam, R. Sarikhani and Z. Ahmadnejad. "Evaluation of water quality using heavy metal index and multivariate statistical analysis in lorestan province, Iran. Journal of Advances in Environmental Health Research, vol. 5, pp. 29-37, 2017.

[69] S. Rapant, M. Rapošová, D. Bodiš, K. Marsina and I. Slaninka. "Environmental-geochemical mapping program in the Slovak Republic". Journal of Geochemical Exploration, vol. 66, pp. 151158, 1999.

[70] L. S. Clesceri, A. D. Eaton, A. E. Greenberg, A. P. H. Association, A. W. W. Association and W. E. Federation. Standard Methods for the Examination of Water and Wastewater. American Public Health Association, Washington, DC, 1998. 